\title{
Effect of Enrichement of Infusion Solutions with Branched Chain Amino Acids in Parenteral Nutrition of Rats
}

\author{
Takeo KIKUCHI, Shoko FUKUdOME, Hitomi IKEMOTO, \\ Ikuko TsuTsui, Hyotaro TANAKA, Yukifumi KOKUBA, ${ }^{1}$ \\ Yoshimasa ORITA, ${ }^{2}$ Kazuo CHIKU, \\ and Yasuo NATORI \\ ${ }^{1}$ Research Laboratories, Morishita Pharmaceutical Co., Ltd., \\ Yasu-gun, Shiga 520-23, Japan \\ ${ }^{2}$ First Department of Internal Medicine, Osaka University Medical School, \\ Fukushima-ku, Osaka 553, Japan \\ ${ }^{3}$ Department of Nutritional Chemistry, School of Medicine, \\ The University of Tokushima, \\ Tokushima 770, Japan
}

(Received September 8, 1986)

Summary The effect of enrichment of the branched chain amino acids (BCAAs) leucine, isoleucine and valine on total parenteral nutrition was studied in rats. Experimental infusion solutions with a sufficient, marginal or deficient level of glucose contained either the conventional amino acid composition $(22.6 \%$ BCAAs) or a BCAA-enriched amino acid composition ( $36 \%$ BCAAs). Rats were infused with experimental solutions for 4 days and several parameters of protein metabolism were evaluated in various tissues. Under conditions of sufficient energy supply, BCAAenriched and conventional groups showed similar body weight gains and muscle protein degradations as measured by urinary 3-methylhistidine excretion. Polysome profiles in the liver and gastrocnemius muscle of the BCAA-enriched group were more heavily aggregated than those of the conventional group. Under the conditions of marginal or deficient energy supply, beneficial effects of BCAA enrichment over the conventional amino acid composition became more evident in terms of better body weight retention, higher RNA/DNA ratio and heavier polysome profile in both liver and muscle, and reduced protein catabolism in muscle. The present study suggests that enrichment of BCAAs, particularly valine and isoleucine, may be useful for nutritional support under hypercatabolic or stressed conditions.

Key Words total parenteral nutrition, branched chain amino acids, protein synthesis, protein degradation, 3-methylhistidine, liver, skeletal muscle

\footnotetext{
1 菊地武夫，福留昌子，池本ひとみ，筒井郁子，田中兵太郎，国場幸史， ${ }^{2}$ 折田義正，

3 知久一雄, 名取靖郎
} 
Recent human and animal studies have indicated that the branched chain amino acids (BCAAs) leucine, isoleucine and valine play a unique role in total parenteral nutrition; BCAA-enriched hyperalimentation in stress has shown beneficial effects on nitrogen retention and protein metabolism(1-3). However, the mechanism of action of the BCAAs on protein synthesis and degradation in various organs remains largely unknown. The present study was designed to evaluate the effects of BCAA enrichment on protein metabolism during parenteral nutrition of rats under various levels of energy supply.

\section{MATERIALS AND METHODS}

Experimental animals and infusion procedure. Male Sprague-Dawley (SD) rats (Charles River Co.) each weighing about $200 \mathrm{~g}$, which had been housed in a controlled environment (temperature $23 \pm 2{ }^{\circ} \mathrm{C}$, and light from 0700 to $1900 \mathrm{~h}$ ) and fed a commercial diet ( $\mathrm{MF}^{\circledR}$, Oriental Co., Tokyo) ad libitium, were used in the experiment. The animals were divided into six body-weight-matched groups of 7-9 animals and prepared for continuous infusion by using techniques similar to those described by Steiger et al.(4).

Experimental design. During the overnight postsurgical recovery period, a $0.9 \%$ saline solution was infused intravenously at the rate of $32.9 \mathrm{ml} / \mathrm{day} / \mathrm{rat}$. On the next day after the surgery, designated as day 0 of the experiment, infusion of the experimental solutions was initiated at the rate of $29.5 \mathrm{ml} / \mathrm{day} /$ rat. The rate was increased to $56.4 \mathrm{ml} / \mathrm{day} / \mathrm{rat}$ on and after day 1 . The compositions of the infusion solutions are shown in Table 1. The solutions contained a sufficient (groups A and B), marginal (groups C and D) or deficient (groups E and F) level of glucose. All the

Table 1. Composition of infusion solutions.

\begin{tabular}{|c|c|c|c|c|c|c|}
\hline Group & A & B & $\mathrm{C}$ & $\mathrm{D}$ & $\mathrm{E}$ & $\mathrm{F}$ \\
\hline Glucose (g/liter) & 208 & 208 & 150 & 150 & 100 & 100 \\
\hline Amino acid (P-1 soln.) (g/liter) & 33 & - & 33 & - & 33 & - \\
\hline (MPR-F soln.) (g/liter) & - & 33 & - & 33 & - & 33 \\
\hline Electrolytes & \multicolumn{6}{|c|}{$\begin{array}{l}\mathrm{Na}^{+}(41.7 \mathrm{mEq} / \text { liter }), \mathrm{K}^{+}(25 \mathrm{mEq} / \text { liter }) \\
\mathrm{Cl}^{-}(19.2 \mathrm{mEq} / \text { liter }), \mathrm{Mg}^{2+}(5 \mathrm{mEq} / \text { liter }) \\
\mathrm{Ca}^{2+}(6.7 \mathrm{mEq} / \text { liter }), \mathrm{P}_{\mathrm{i}}(6.7 \mathrm{mM} / \text { liter })\end{array}$} \\
\hline Vitamins & \multicolumn{6}{|c|}{$\begin{array}{l}\text { A ( } 1,000 \mathrm{IU} / \text { liter }), \mathrm{D}_{2}(100 \mathrm{IU} / \text { liter }), \mathrm{E}(0.5 \mathrm{mg} / \text { liter }) \text {, } \\
\mathrm{B}_{1}(5 \mathrm{mg} / \text { liter }), \mathrm{B}_{2}(1 \mathrm{mg} / \text { liter }), \mathrm{B}_{6}(1.5 \mathrm{mg} / \text { liter }), \\
\text { nicotinamide }(10 \mathrm{mg} / \text { liter }), \text { pantothenic acid } \\
(2.5 \mathrm{mg} / \text { liter }), \mathrm{C}(50 \mathrm{mg} / \text { liter })\end{array}$} \\
\hline Trace elements & \multicolumn{6}{|c|}{$\begin{array}{l}\mathrm{Fe}(0.5 \mathrm{mg} / \text { liter }), \mathrm{Zn}(0.75 \mathrm{mg} / \text { liter }) \\
\mathrm{Cu}(0.075 \mathrm{mg} / \text { liter }), \mathrm{I}(0.038 \mathrm{mg} / \text { liter })\end{array}$} \\
\hline
\end{tabular}


Table 2. Composition of amino acids in infusion solutions.

\begin{tabular}{|c|c|c|}
\hline & P-1 & MPR-F \\
\hline & \multicolumn{2}{|c|}{ (g/liter) } \\
\hline L-Ile & 3.03 & 1.87 \\
\hline L-Leu & 4.30 & 4.17 \\
\hline L-Lys & 2.36 & 2.93 \\
\hline L-Met & 1.47 & 1.17 \\
\hline L-Phe & 2.33 & 3.12 \\
\hline L-Thr & 2.50 & 2.17 \\
\hline L-Trp & 0.43 & 0.43 \\
\hline L-Val & 4.67 & 1.50 \\
\hline L-Ala & 2.37 & 2.07 \\
\hline L-Arg & 3.00 & 2.63 \\
\hline L-Asp & 0.33 & 1.27 \\
\hline L-Cys & - & 0.33 \\
\hline L-Glu & 0.17 & 2.17 \\
\hline L-His & 1.67 & 2.00 \\
\hline L-Pro & 1.67 & 1.10 \\
\hline L-Ser & 0.57 & 0.73 \\
\hline L-Tyr & 0.13 & 0.12 \\
\hline Gly & 2.33 & 3.57 \\
\hline Total & 33.33 & 33.35 \\
\hline EAA/NEAA & 1.72 & 1.09 \\
\hline BCAA ( $\%)$ & 36.0 & 22.6 \\
\hline
\end{tabular}

solutions also contained $33 \mathrm{~g}$ of amino acids per liter either in the form of P-1 solution (groups A, C, and E) or MPR-F solution (groups B, D, and F). As shown in Table 2, MPR-F solution has a conventional or standard amino acid composition, contained $22.6 \%$ BCAA. P-1 solution is a BCAA-enriched solution, containing as much as $36 \%$ BCAAs. Of the three BCAAs, the amounts of valine and isoleucine are particularly enriched over the composition of MPR-F solution. Infusion of the experimental solutions was continued for 4 consecutive days. The daily intakes of energy were $54 \mathrm{kcal}$ in groups A and B, $42 \mathrm{kcal}$ in groups C and D, and $30 \mathrm{kcal}$ in groups $\mathrm{E}$ and $\mathrm{F}$ on and after day 1 .

Measurements. Changes in body weights during the infusion were measured daily. Urine was collected quantitatively each day and analyzed for outputs of creatinine and 3-methylhistidine. Urinary creatinine was determined by the Jaffe reaction (5) and urinary 3-methylhistidine by the high-performance liquid chromatographic method (6).

On the last day of the test period, blood was withdrawn from the abdominal aorta under pentobarbital anesthesia immediately after termination of infusion. Plasma was analyzed for total protein(7), albumin(8), transferrin (9) and urea 
nitrogen (10).

The liver, gastrocnemius muscle and epididymal fat pads were excised and weighed. DNA (11), RNA(11) and protein (12) contents of the liver and gastrocnemius muscle were determined.

Results were expressed as means \pm SEM. All data were subjected to analysis of variance and, when appropriate, differences between group means were tested for significance with Student's $t$-test or Cochran-Cox's method(13). Results were considered significant when $p$ was less than 0.05 .

Preparation and analysis of polysomes. Rats were killed by decapitation on the last day of the test period, and livers and gastrocnemius muscles were quickly excised. The tissues were immediately frozen in liquid nitrogen and kept in a ultrafreezer at $-70^{\circ} \mathrm{C}$ until use. Polysomes were prepared from the tissues and analyzed by sucrose density gradient centrifugation as described previously (14). The method for the quantitative representation of the degree of aggregation of polysomes is illustrated in Fig. 1. The area of polysomes (larger than trimers) above the baseline was divided into two parts (small and large polysomes) by a perpendicular line drawn from the middle point (B) between $\mathrm{A}$ and $\mathrm{C}$, and the proportion of the heavy (large) polysomes to the total polysomes was calculated. The values were expressed as means \pm SEM of the percentage of heavy polysomes among total polysomes. The polysomal samples from various groups analyzed in the same sucrose-densitygradient centrifugal run were considered as experimental pairs, and the paired $t$ test (13) was used to compare the mean values of the percentage of heavy polysomes between experimental groups. When $p$ was less than 0.05 , the differences were regarded as statistically significant.

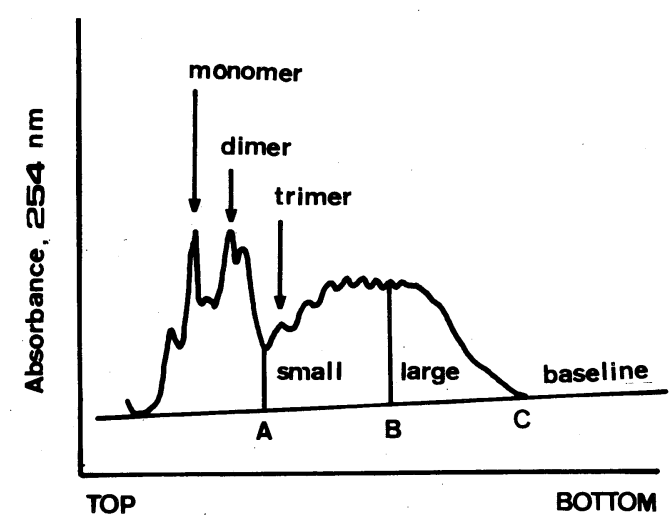

Fig. 1. Quantitative estimation of the degree of aggregation of polysomes. (See text for explanation.)

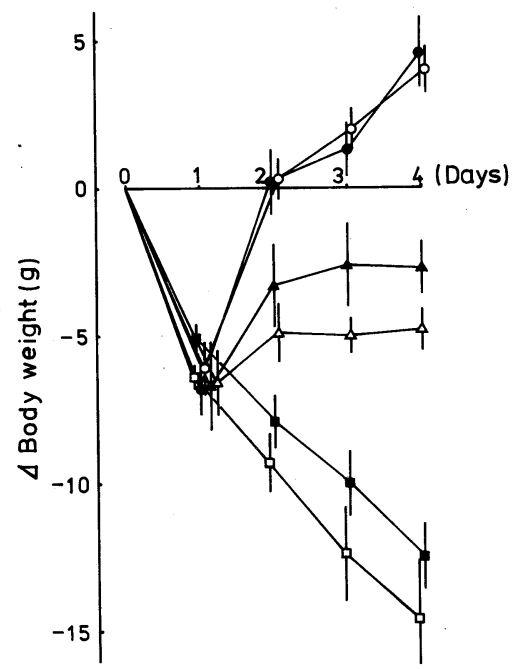

Fig. 2.

J. Nutr. Sci. Vitaminol. 


\section{RESULTS}

Nutritional status of animals during infusion of BCAA-enriched or conventional infusates

Figure 2 shows the growth of rats infused with various test solutions. On day 1 the rats in each group showed body weight loss. On and after day 2 the rats in groups A and B, provided with sufficient energy, markedly gained body weight, but there was no significant difference in the body weight gain between the two groups. Rats in groups C and D, with marginal energy, barely maintained body weight, but the rats in group $C$ tended to fare better than the rats in group D. Rats in groups $\mathrm{E}$ and $\mathrm{F}$, with deficient energy, lost weight during the infusion period. The loss of body weight in group $\mathrm{E}$, however, had a tendency to be smaller than that in group F.

Table 3. Organ weights after 4 days of infusion.

\begin{tabular}{|c|c|c|c|c|c|c|}
\hline \multirow[b]{2}{*}{ Group } & \multicolumn{2}{|c|}{ Liver } & \multicolumn{2}{|c|}{ Muscle $^{\mathrm{a}}$} & \multicolumn{2}{|c|}{ Fat $(E F P)^{a}$} \\
\hline & $\begin{array}{l}\text { Absolute } \\
\text { (g) }\end{array}$ & $\begin{array}{l}\text { Relative } \\
(\%)\end{array}$ & $\begin{array}{l}\text { Absolute } \\
\text { (g) }\end{array}$ & $\begin{array}{c}\text { Relative } \\
(\%)\end{array}$ & $\begin{array}{l}\text { Absolute } \\
\text { (g) }\end{array}$ & $\begin{array}{l}\text { Relative } \\
(\%)\end{array}$ \\
\hline A & $6.90 \pm 0.19$ & $3.69 \pm 0.09$ & $2.35 \pm 0.05$ & $1.26 \pm 0.02$ & $1.11 \pm 0.04$ & $0.60 \pm 0.02$ \\
\hline B & $6.92 \pm 0.19$ & $3.71 \pm 0.09$ & $2.37 \pm 0.03$ & $1.27 \pm 0.02$ & $1.03 \pm 0.05$ & $0.55 \pm 0.02$ \\
\hline $\mathrm{C}$ & $6.07 \pm 0.14$ & $3.39 \pm 0.09$ & $2.24 \pm 0.04$ & $1.25 \pm 0.02$ & $0.92 \pm 0.08$ & $0.51 \pm 0.04$ \\
\hline D & $5.89 \pm 0.13$ & $3.35 \pm 0.07$ & $2.30 \pm 0.04$ & $1.31 \pm 0.02$ & $0.80 \pm 0.05$ & $0.46 \pm 0.03$ \\
\hline $\mathrm{E}$ & $5.38 \pm 0.15$ & $3.19 \pm 0.07$ & $2.25 \pm 0.04] *$ & $1.33 \pm 0.017 *$ & $0.61 \pm 0.05$ & $0.36 \pm 0.02$ \\
\hline $\mathrm{F}$ & $5.47 \pm 0.15$ & $3.27 \pm 0.07$ & $2.09 \pm 0.04\rfloor$ & $1.25 \pm 0.02\rfloor$ & $0.66 \pm 0.09$ & $0.39 \pm 0.05$ \\
\hline
\end{tabular}

${ }^{a}$ Absolute and relative weights presented as the sum of right and left organs.

* Significant difference at $p<0.05$.

Table 4. Blood chemistry after 4 days of infusion.

\begin{tabular}{ccccc}
\hline Group & $\begin{array}{c}\text { Total protein } \\
(\mathrm{g} / 100 \mathrm{ml})\end{array}$ & $\begin{array}{c}\text { Albumin } \\
(\mathrm{g} / 100 \mathrm{ml})\end{array}$ & $\begin{array}{c}\text { Transferrin } \\
(\mathrm{mg} / 100 \mathrm{ml})\end{array}$ & $\begin{array}{c}\text { Urea nitrogen } \\
(\mathrm{mg} / 100 \mathrm{ml})\end{array}$ \\
\hline A & $4.58 \pm 0.08$ & $2.37 \pm 0.04$ & $359 \pm 8$ & $10.0 \pm 0.6$ \\
B & $4.57 \pm 0.09$ & $2.39 \pm 0.07$ & $357 \pm 8$ & $10.8 \pm 0.5$ \\
C & $4.36 \pm 0.09$ & $2.24 \pm 0.04$ & $338 \pm 4$ & $12.9 \pm 0.5$ \\
D & $4.36 \pm 0.07$ & $2.26 \pm 0.06$ & $333 \pm 7$ & $14.6 \pm 0.9$ \\
E & $4.60 \pm 0.05$ & $2.34 \pm 0.04$ & $341 \pm 6$ & $16.8 \pm 0.5$ \\
F & $4.53 \pm 0.07$ & $2.28 \pm 0.05$ & $338 \pm 3$ & $17.6 \pm 1.1$ \\
\hline
\end{tabular}

Fig. 2. Body weight changes of rats infused with various test solutions. group $\mathrm{A} ; \mathrm{O}$, group $\mathrm{B} ; \boldsymbol{\Delta}$, group $\mathrm{C} ; \triangle$, group $\mathrm{D}$; $\mathbf{\square}$, group $\mathrm{E} ; \square$, group $\mathrm{F}$. Values represent means \pm SEM for $7-9$ rats in each group.

Vol. 33, No. 1, 1987 
Table 5. Cell composition in liver and muscle after 4 days of infusion.

\begin{tabular}{|c|c|c|c|c|}
\hline \multirow{2}{*}{ Group } & \multicolumn{2}{|c|}{ Liver } & \multicolumn{2}{|c|}{ Muscle } \\
\hline & RNA/DNA & Protein/DNA & RNA/DNA & Protein/DNA \\
\hline A & $2.79 \pm 0.06$ & $64.7 \pm 1.5]_{*}$ & $2.13 \pm 0.12$ & $337 \pm 14$ \\
\hline B & $2.56 \pm 0.09$ & $58.5 \pm 1.7\rfloor^{\top}$ & $2.01 \pm 0.09$ & $305 \pm 13$ \\
\hline $\mathrm{C}$ & $2.49 \pm 0.10$ & $53.4 \pm 2.7$ & $2.21 \pm 0.07$ & $346 \pm 8$ \\
\hline D & $2.38 \pm 0.05$ & $50.9 \pm 1.0$ & $2.08 \pm 0.06$ & $326 \pm 9$ \\
\hline $\mathrm{E}$ & $2.24 \pm 0.09$ & $57.0 \pm 2.3$ & $2.00 \pm 0.09$ & $361 \pm 8$ \\
\hline $\mathrm{F}$ & $2.21 \pm 0.06$ & $54.0 \pm 1.1$ & $1.81 \pm 0.05$ & $349 \pm 4$ \\
\hline
\end{tabular}

* Significant difference at $p<0.05$.

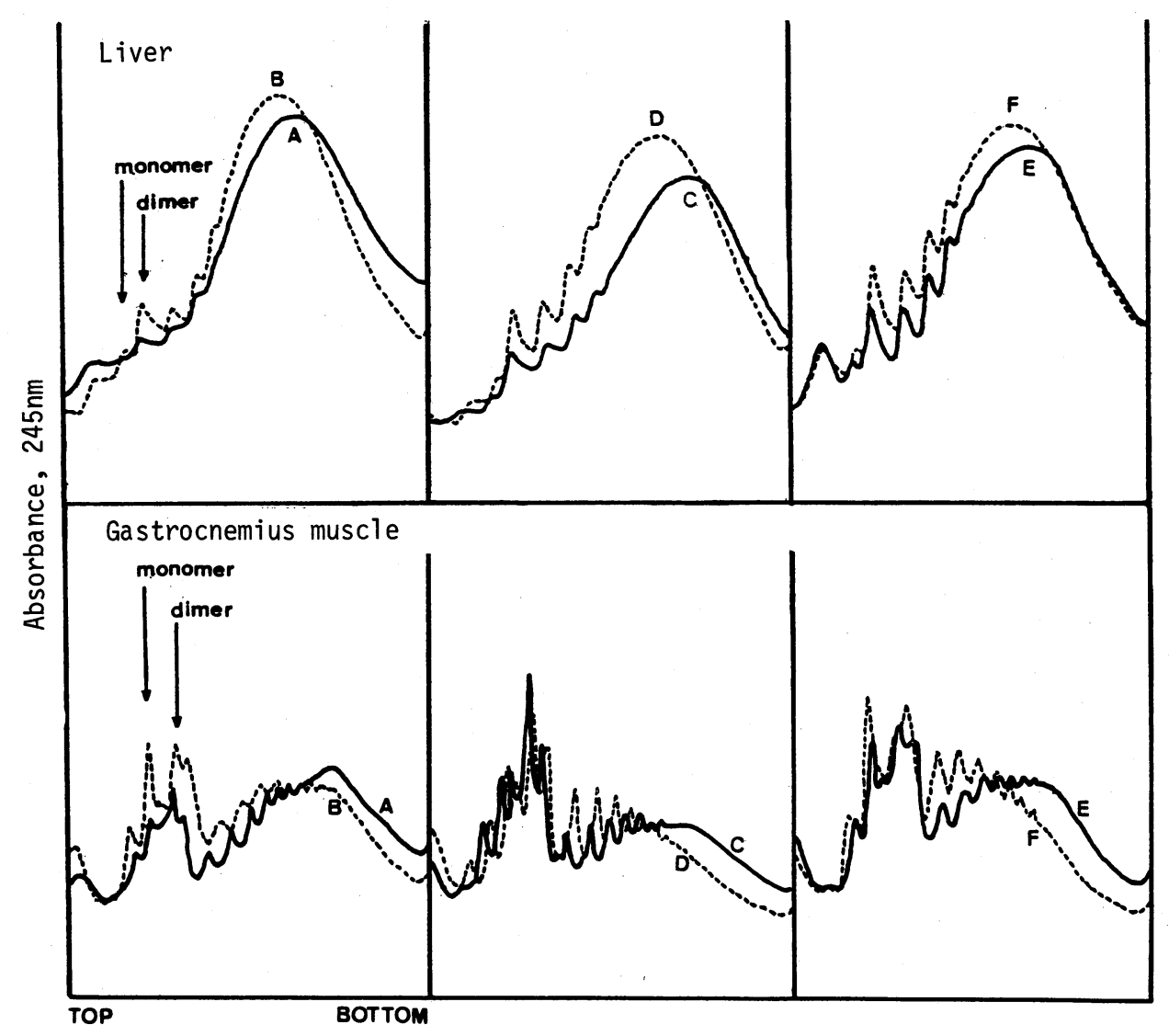

Fig. 3. Sedimentation patterns of liver (upper frame) and gastrocnemius muscle (lower frame) polysomes after 4-day infusion period of various test solutions. A, B, C, D, $\mathrm{E}$, and $\mathrm{F}$ represent experimental groups. 
Weights of various organs after 4 days of infusing different solutions are shown in Table 3. Although the decrease in energy intakes generally caused reduction in organ weights, there were no significant differences in the weights of the liver, gastrocnemius muscle and epididymal fat pads between the rats in goups $\mathrm{A}$ and $\mathbf{B}$, or groups $\mathrm{C}$ and D. However, the weight of the gastrocnemius muscle in group $\mathrm{E}$ was found to be significantly heavier than that in group $\mathrm{F}$.

Laboratory data on the blood constituents after infusion are presented in Table 4. The concentrations of plasma total protein, albumin and transferrin were not significantly different between any group. The concentration of urea nitrogen was increased with decreasing energy intake, but no difference was observed between the conventional and BCAA-enriched groups.

\section{Cell composition and polysome profile in liver and muscle}

The abundance of ribosomes and other RNA-containing components is generally correlated with the rate of protein synthesis in a tissue (15). The ratios of RNA and protein to DNA in the liver and gastrocnemius muscle after 4 days of infusion are given in Table 5. These ratios in both the liver and muscle of rats in groups $\mathrm{A}, \mathrm{C}$, and $\mathrm{E}$ were higher or tended to be higher than the values in the corresponding groups $\mathrm{B}, \mathrm{D}$, and $\mathrm{F}$, suggesting that infusion of BCAA-enriched solutions enhances the protein synthetic activity in both the liver and muscle.

Polysomes were prepared from the liver and gastrocnemius muscle and analyzed by sucrose density gradient centrifugation. A representative profile in each experimental group is shown in Fig. 3. It is evident that polysomes from BCAAenriched groups $\mathrm{A}, \mathrm{C}$, and $\mathrm{E}$ are more heavily aggregated than those from corresponding conventional groups $\mathrm{B}, \mathrm{D}$, and $\mathrm{F}$ in both the liver and muscle. The proportions of the heavy polysomes to the total polysomes were calculated from the polysome profiles in each group and the results are given in Table 6. Lower energy supply caused disaggregation of polysomes in both tissues but the proportion of polysomes in the BCAA-enriched groups was clearly higher than that in the

Table 6. Proportion of heavy polysomes among total polysomes from the liver and gastrocnemius muscles of rats after 4 days of infusion. ${ }^{\mathrm{a}}$

\begin{tabular}{|c|c|c|}
\hline Group & Liver & Muscle \\
\hline A & $39.3 \pm 2.90]_{*}$ & $29.8 \pm 4.30]_{*}$ \\
\hline B & $32.5 \pm 2.34]^{*}$ & $24.3 \pm 3.16]^{*}$ \\
\hline $\mathrm{C}$ & $37.6 \pm 3.97]_{*}$ & $24.2 \pm 3.51]_{*}$ \\
\hline $\mathrm{D}$ & $30.5 \pm 2.26\rfloor^{*}$ & $15.9 \pm 3.89]^{*}$ \\
\hline $\mathrm{E}$ & $32.0 \pm 3.02]_{*}$ & $21.4 \pm 4.31]_{*}$ \\
\hline F & $28.6 \pm 2.83]^{*}$ & $16.1 \pm 2.93]^{*}$ \\
\hline
\end{tabular}

${ }^{a}$ Values are expressed as \% heavy polysomes among total polysomes, calculated as described in MATERIALS AND METHODS. * Significant difference at $p<0.05$ or more. 
Table 7. Excretion of 3-methylhistidine (3-MH) and creatinine $(\mathrm{Cr})$ on day 4 of infusion.

\begin{tabular}{clcl}
\hline Group & $\begin{array}{c}3-\mathrm{MH} \\
(\mu \mathrm{mol} / \mathrm{day})\end{array}$ & $\begin{array}{c}\mathrm{Cr} \\
(\mu \mathrm{mol} / \mathrm{day})\end{array}$ & $\begin{array}{c}3-\mathrm{MH} / \mathrm{Cr} \\
\left(\times 10^{-2}\right)\end{array}$ \\
\hline A & $1.63 \pm 0.08$ & $50.9 \pm 2.2$ & $3.20 \pm 0.06$ \\
B & $1.62 \pm 0.10$ & $50.0 \pm 2.1$ & $3.23 \pm 0.11$ \\
C & $1.32 \pm 0.06$ \\
D & $1.51 \pm 0.05$ & $47.4 \pm 1.7$ & $2.79 \pm 0.06$ \\
E & $1.49 \pm 0.09$ & $49.5 \pm 1.6$ & $3.05 \pm 0.07$ \\
F & $1.62 \pm 0.28$ & $44.7 \pm 2.0$ & $3.34 \pm 0.18$ \\
& & $42.4 \pm 3.1$ & $3.77 \pm 0.54$ \\
\hline
\end{tabular}

* Significant difference at $p<0.05$.

corresponding groups infused with the conventional amino acid composition. This result indicates that $\mathrm{BCAA}$ enrichment in the infusion solution definitely exerts a beneficial effect on protein synthesis in both the liver and muscle.

\section{Urinary excretion of creatinine and 3-methylhistidine}

The urinary excretion of creatinine and 3-methylhistidine was determined in each group on the last day (day 4) of the infusion period. As shown in Table 7, creatinine excretion, which is proportional to the muscle mass, was reduced as the energy supply was reduced. The excretion of 3-methylhistidine, which serves as an index of the catabolic rate of muscle (16), was the same for groups A and B with sufficient energy supply. However, the excretion of 3-methylhistidine and the ratio of 3-methylhistidine to creatinine in BCAA-enriched groups were lower than those in conventional groups when the energy supply was limited to the marginal (groups C and D) or deficient (groups E and F) level. Since lower 3-methylhistidine excretion is indicative of lower rates of muscle catabolism(16), the present observation suggests that BCAA-enriched infusion solution may inhibit muscle protein degradation when the energy supply is suboptimal.

\section{DISCUSSION}

In the present study, we investigated the effects of parenteral infusion of BCAA-modified amino acid solutions on protein metabolism in rats. The principal modifications were the enrichment of conventional balanced amino acid solutions with BCAAs, particularly with valine and isoleucine. The ratio of leucine : isoleucine : valine in the conventional MPR-F solution is $1.0: 0.45: 0.36$. This ratio was changed to $1.0: 0.71: 1.09$ in the BCAA-enriched P-1 solution. The rationale for this was research results demonstrating the increased oxidation of BCAAs, not only leucine but also isoleucine and valine, under stress along with an increased demand to meet protein synthesis in the liver and muscle(1-3). The increase in BCAA 
contents in P-1 solution was counterbalanced by a decrease in the contents of some non-essential amino acids in MPR-F solution, notably glutamic acid, aspartic acid and glycine. It is unlikely that the effect of $\mathrm{P}-1$ solution on protein metabolism was due to the decrease in the contents of these non-essential amino acids, rather than to the increase in BCAA contents.

The protein synthetic activity was evaluated by determining RNA/DNA ratios and polysome profiles in tissues. The degree of aggregation of polysomes was estimated by measuring the proportion of ribosomes (monomers and dimers) to the total polysomes (larger than trimers) found in a previous study (14) and the ratio of heavy polysomes to the total polysomes was calculated in the present study. The present method was found to reflect changes in the compositions of parenteral infusion solutions more sensitively than did the previous method.

Recent evidence suggests that 3-methylhistidine liberated by muscle protein degradation is not reutilized for protein synthesis and is almost completely excreted in urine (16). Therefore, the urinary excretion of 3-methylhistidine was measured as an index of the catabolic rate of muscle.

Rats infused with the solutions containing sufficient energy showed the same body weight gains, irrespective of whether the solution contained the BCAAenriched amino acid composition (group A) or the conventional amino acid composition (group B). While 3-methylhistidine excretion was the same for both groups, polysome profiles in the liver and muscle of group A rats were more heavily aggregated than those of group B rats. Possibly the infusion period of 4 days was too short to manifest the effect of increased protein anabolism by BCAA-enriched solution in terms of body weight gain and other physiological parameters.

Under the conditions of marginal (groups $C$ and D) or deficient (groups $E$ and F) energy supplies, the beneficial effects of BCAA enrichment became more apparent; BCAA-enriched solutions, compared with solutions with the conventional amino acid composition, counteracted body weight loss, showed higher protein synthetic activities in terms of RNA/DNA ratios and polysome profiles in both the liver and muscle, and caused inhibition of muscle protein degradation as judged by less excretion of 3-methylhistidine.

Among the various parameters of protein metabolism examined in the present study, the analysis of polysome profiles served as the most significant index of protein synthesis under various nutritional conditions. We recently demonstrated that the study of polysome profiles offers a rapid and sensitive index of the state of protein synthesis in individual tissues (14).

The present findings agree with recent studies showing the beneficial effects of BCAA-enriched hyperalimentation under various stress conditions (1-3). Precisely how BCAAs exert their anabolic effect on the liver and skeletal muscle is not completely understood. The BCAAs are unique in that they are the only amino acids not metabolized in the liver; instead, they are metabolized in muscle, heart and kidney tissues (17). Direct oxidation by muscle tissue is particularly important, as the BCAAs serve as a valuable alternate energy substrate for dextrose and fat in

Vol. 33, No. 1, 1987 
stressed states (18).

The BCAAs, and leucine in particular, are reported to promote protein synthesis $(19,20)$, but the reverse view has also recently been expressed $(21)$. Nachbauer et al.(22) reported that leucine is the key amino acid among the BCAAs for reducing skeletal muscle proteolysis, but the mechanism of action remains unknown.

Most investigators have suggested that leucine is the critical BCAA in the reduction of muscle protein breakdown and increased synthesis. However, in normal humans, ingestion of a leucine meal resulted in leucine uptake but glutamate release and net nitrogen loss in the forearm muscle (23). Freund et al. (24) showed in an animal model that infusion of valine improved the nitrogen balance significantly more than did the administration of leucine or isoleucine. Daly et al. (25) infused patients undergoing cystectomy and ileal loop diversion with BCAA-enriched solution and found that a significant uptake of total amino acid and BCAA into the forearm muscle and better nitrogen balance was due to BCAAs other than leucine.

In the BCAA-enriched (P-1) solution presently employed, valine and isoleucine, but not so much leucine, were greatly enriched compared to the composition of the conventional (MRP-F) infusion solution. The present study suggests that enrichment of BCAAs, particularly valine and isoleucine, may be useful for the nutritional support of hypercatabolic or stressed patients.

\section{REFERENCES}

1) Cerra, F. B., Mazuski, J. E., Chute, E., Nuwer, N., Teasley, K., Lysne, J., Shronts, E. P., and Konstantinides, F. N. (1984): Branched chain metabolic support. A prospective, randomized, double-blind trial in surgical stress. Ann. Surg., 199, 286-291.

2) Nuwer, N., Cerra, F. B., Shronts, E., Lysne, J., Teasley, K. M., and Konstantinides, F. N. (1983): Does modified amino acid total parenteral nutrition alter immune response in high level surgical stress? JPEN, 7, 521-524.

3) Cerra, F. B. (1985): Branched chain amino acids, part I: Stress nutrition. Nutr. Support Services, 5, 8-40.

4) Steiger, E., Vars, H. M., and Dudrick, S. J. (1972): A technique for long-term intravenous feeding in unrestrained rats. Arch. Surg., 104, 330-332.

5) Bonsnes, R. W., and Tassky, H. H. (1949): On the colorimetric determination of creatinine by the Jaffe reaction. J. Biol. Chem., 158, 581-591.

6) Friedman, Z., and Smith, H. W. (1980): Rapid high-performance liquid chromatography method for quantitation of 3-methylhistidine. J. Chromatogr., 182, 414-418.

7) Gornall, A. G., Bardawill, C. J., and David, M. M. (1949): Determination of serum proteins by means of the biuret reaction. J. Biol. Chem., 177, 751-766.

8) Doumas, B. T., Watson, W. A., and Biggs, H. G. (1971): Albumin standards and the measurement of serum albamin with bromcresol green. Clin. Chim. Acta, 31, 87-96.

9) Miller, J. M., and Thirkettle, C. (1975): The fluorimetric determination of transferrin in blood serum. Biochem. Med., 13, 98-100.

10) Searcy, R. J., and Cox, F. M. (1963): A modified technique for ultramicro estimation of urea nitrogen. Clin. Chim. Acta, 8, 810-812.

11) Karsten, U., and Wollenberger, A. (1978): Determination of DNA and RNA in 
homogenized cells and tissues by surfaced fluorometry. Anal. Biochem., 46, 135-148.

12) Lowry, O. H., Rosebrough, N. J., Farr, A. L., and Randall, R. J. (1972): Protein measurement with folin phenol reagent. J. Biol. Chem., 193, 265-275.

13) Cochran, W. G., and Cox, G. M. (1950): Experimental Designs, John Wiley \& Sons, New York.

14) Kikuchi, T., Okamoto, H., Chiku, K., and Natori, Y. (1986): Effects of glucose and amino acid depletions on protein synthetic parameters in liver and skeletal muscle of rats during parenteral nutrition. J. Nutr. Sci. Vitaminol., 32, 601-612.

15) Munro, H. N. (1970): A general survey of mechanisms regulating protein metabolism in mammals, in Mammalian Protein Metabolism, Vol. IV, ed by Munro, H. N., Academic Press, New York, pp. 3-130.

16) Young, V. R., and Munro, H. N. (1978): 3-Methylhistidine and muscle protein turnover: an overview. Fed. Proc., 37, 2291-2300.

17) Felig, P. (1975): Amino acid metabolism in man. Annu. Rev. Biochem., 44, 933-955.

18) Adibi, S. A., Krzysik, B. A., Morse, E. M., Amin, P. M., and Allen, E. R. (1974): Oxidative energy metabolism in the skeletal muscle: biochemical and ultrastructural evidence for adaptive changes. J. Lab. Clin. Med., 83, 548-562.

19) Buse, M. G., and Weigand, D. A. (1977): Studies concerning the specificity of the effect of leucine on the turnover of proteins in muscle of control and diabetic rats. Biochim. Biophys. Acta, 475, 81-89.

20) Buse, M. G., and Reid, S. S. (1975): Leucine: a possible regulator of protein turnover in muscle. J. Clin. Invest., 56, 1250-1261.

21) McNurlan, M. A., Fern, E. B., and Garlick, P. J. (1982): Failure of leucine to stimulate protein synthesis in vivo. Biochem. J., 204, 831-838.

22) Nachbauer, C. A., James, J. H., Edwards, L. L., Ghory, M. J., and Fischer, J. E. (1984): Infusion of branched chain-enriched amino acid solutions in sepsis. Am. J. Surg., 147, 743-752.

23) Aoki, T. T., Brennan, M. F., Fitzpatrick, G. F., and Knight, D. C. (1981): Leucine meal increases glutamine and total nịtrogen release from forearm muscle. J. Clin. Invest., 68, $1522-1528$.

24) Freund, H., James, J. H., and Fischer, J. E. (1981): Nitrogen sparing mechanisms of singly administered branched chain amino acids in the injured rat. Surgery, 90, 237-243.

25) Daly, J. M., Mihranian, M. H., Kehoe, J. E., and Brennan, M. F. (1983): Effects of postoperative infusion of branched chain amino acids on nitrogen balance and forearm muscle substrate flux. Surgery, 94, 151-158. 